\title{
URGENSI PEMBENTUKAN UNDANG-UNDANG HAK ANGKET DPR RI \\ THE URGENCY OF MAKING THE LAW ON THE RIGHT OF INQUIRY OF THE HOUSE OF REPRESENTATIVES OF THE REPUBLIC OF INDONESIA
}

\author{
Novianto M. Hantoro \\ Pusat Penelitian Badan Keahlian DPR RI \\ Komplek MPR/DPR/DPD Gedung Nusantara I Lantai 2, \\ Jl. Jenderal Gatot Subroto Jakarta \\ Email:nmhantoro@yahoo.com \\ Naskah diterima: 15 Agustus 2017 \\ Naskah direvisi: 18 September 2017 \\ Naskah diterbitkan: 30 November 2017
}

\begin{abstract}
Prior to the decision of the Constitutional Court (MK), the implementation of the right to inquiry was regulated in two laws, namely Law No. 6 of 1954 on the Establishment of the Rights of Inquiry of the House of Representatives (DPR) and Law No. 27 of 2009 on MPR, DPR, DPD, and DPRD. Through proposal for judicial review, MK decided the Law on the Rights of Inquiry was null and void because it was not in accordance with the presidential system adopted in the 1945 Constitution. Today, the exercise of the right of inquiry is only based on Law on MPR, DPR, DPD, and DPRD. Nonetheless, the Amendment of Law No. 27 of 2009 into Law No. 17 of 2014 could not accommodate some substances of the null and void Law on the Rights of Inquiry. The urgency of the formulation of the law on the right to inquiry, other than to carry out the Constitutional Court's decision; are to close the justice gap of the current regulation; to avoid multi-interpretation of the norm, for example on the subject and object of the right of inquiry; and to execute the mandate of Article 20A paragraph (4) of the 1945 Constitution. The regulation on the right to inquiry shall be formulated separately from the Law on MPR, DPR, DPD and DPRD, with at least several substances to be discussed, namely: definition, mechanisms, and procedure, as well as examination of witnesses, expert, and documents.
\end{abstract}

Keywords: right of inquiry, law, the House of Representatives

\begin{abstract}
Abstrak
Sebelum adanya putusan Mahkamah Konstitusi (MK), pelaksanaan hak angket diatur dalam dua undang-undang, yaitu Undang-Undang Nomor 6 Tahun 1954 tentang Penetapan Hak Angket DPR (UU Angket) dan Undang-Undang Nomor 27 Tahun 2009 tentang Majelis Permusyawaratan Rakyat, Dewan Perwakilan Rakyat, Dewan Perwakilan Daerah, dan Dewan Perwakilan Rakyat Daerah (UU MPR, DPR, DPD, dan DPRD). Melalui permohonan pengujian undang-undang, MK membatalkan keberlakuan UU Angket karena sudah tidak sesuai dengan sistem presidensial yang dianut dalam UUD 1945. Pelaksanaan hak angket saat ini hanya berdasarkan UU MPR, DPR, DPD, dan DPRD. Penggantian UU No. 27 Tahun 2009 menjadi UU No. 17 Tahun 2014 tentang MPR, DPR, DPD, dan DPRD ternyata tidak mengakomodasi beberapa substansi UU Angket yang telah dibatalkan. Berdasarkan hal tersebut, terdapat urgensi untuk membentuk Undang-Undang tentang Hak Angket DPR RI. Urgensi tersebut, selain sebagai tindak lanjut putusan MK, juga untuk menutup celah kekosongan hukum pada pengaturan saat ini dan untuk menghindari multi-interpretasi norma, misalnya terhadap subjek dan objek hak angket. Pengaturan mengenai hak angket perlu diatur di dalam undang-undang yang terpisah dari UU MPR, DPR, DPD, dan DPRD, dengan materi muatan yang berisi tentang pengertian-pengertian, mekanisme, dan hukum acara. Pembentukan UndangUndang tentang Hak Angket diperlukan guna memenuhi amanat Pasal 20A ayat (4) UUD 1945.

Kata kunci: hak angket, undang-undang, DPR RI
\end{abstract}




\section{PENDAHULUAN}

Ketentuan mengenai hak angket Dewan Perwakilan Rakyat Republik Indonesia (DPR) diatur dalam Pasal 20A Undang-Undang Dasar Negara Republik Indonesia Tahun 1945 (UUD 1945) yang menyebutkan bahwa dalam melaksanakan fungsinya, selain hak yang diatur dalam pasal-pasal lain Undang-Undang Dasar ini, DPR mempunyai hak interpelasi, hak angket, dan hak menyatakan pendapat. Pasal 20 ayat (4) UUD 1945 mengamanatkan ketentuan lebih lanjut tentang hak DPR dan hak anggota DPR diatur dalam undang-undang.

Undang-undang yang mengatur secara khusus mengenai hak angket adalah UndangUndang Nomor 6 Tahun 1954 tentang Penetapan Hak Angket Dewan Perwakilan Rakyat (UU Angket). Dasar hukum undangundang ini bukan Pasal 20A UUD 1945, melainkan Pasal 70 Undang-Undang Dasar Sementara 1950 (UUDS) yang menyatakan: "Dewan Perwakilan Rakjat mempunjai hak menjelidiki (enquete), menurut aturan-aturan jang ditetapkan dengan undang-undang". UU Angket ini kemudian dibatalkan oleh Mahkamah Konstitusi (MK) dalam Perkara Nomor 8/PUU. VIII/2010.

Pengujian UU Angket bukan pada substansi hak angket sebagai hak konstitusional DPR, melainkan karena dua landasan hukum yang digunakan secara bersamaan pada saat itu, yaitu UU No. 27 Tahun 2009 tentang MPR, DPR, DPD, dan DPRD, serta UU Angket. Pembatalan UU Angket diputuskan dengan pertimbangan bahwa UU Angket termasuk undang-undang yang tidak dapat diteruskan keberlakuannya karena terdapat perbedaan sistem pemerintahan yang dianut dari kedua konstitusi yang mendasarinya, sehingga materi muatan UU Angket bertentangan dengan UUD 1945.

UU No. 27 Tahun 2009 tentang MPR, DPR, DPD, dan DPRD kemudian telah diganti dengan UU No. 17 Tahun 2014, sehingga pengaturan mengenai hak angket saat ini diatur dalam Undang-Undang No. 17 Tahun 2014 tentang MPR, DPR, DPD, dan DPRD (UU MD3). Penggantian tersebut tidak secara signifikan menyempurnakan ketentuan mengenai pelaksanaan hak angket. Ketentuan lebih lanjut sebagai penjabaran undang-undang diamanatkan untuk diatur di dalam Peraturan DPR tentang Tata Tertib (Tatib). Baik UU MD3 maupun Tatib DPR, tidak mengatur secara tuntas ketentuan formil dan materiil mengenai tata cara pelaksanaan hak angket.

Pengaturan yang tidak komprehensif tentang pelaksanaan hak angket DPR RI mengakibatkan terjadinya multi-interpretasi. Hal ini dapat dilihat pada pelaksanaan hak angket terhadap pelaksanaan tugas dan kewenangan Komisi Pemberantasan Korupsi (KPK). Panitia angket untuk menyelidiki pelaksanaan tugas dan kewenangan KPK terbentuk berdasarkan Keputusan DPR RI Nomor 1/DPR RI/V/2016-2017 tanggal 30 Mei 2017, serta telah diumumkan dalam Berita Negara Nomor 53 tanggal 4 Juli 2017.

Perbedaan penafsiran terjadi, di antaranya, terhadap kategori objek hak angket, prosedur dan mekanisme kerja panitia angket, termasuk hukum acara untuk menghadirkan saksi di dalam persidangan panitia angket. Salah satu indikasi adanya perbedaan penafsiran dapat dilihat dari permohonan uji materi terhadap UU MD3, antara lain pada perkara Nomor 36/PUU-XV/2017, perkara Nomor 37/PUUXV/2017, perkara Nomor 40/PUU-XV/2017, dan perkara Nomor 47/PUU-XV/2017, yang pada intinya mempersoalkan rumusan Pasal 79 ayat (3) mengenai pengertian hak angket.

Putusan MK yang membatalkan UU Angket dan pengaturan pelaksanaan hak angket di dalam UU MD3 dan Tatib yang kurang komprehensif dan multi-interpretasi mengakibatkan perlunya dilakukan kajian mengenai bagaimana seharusnya pengaturan pelaksanaan hak angket DPR. Berdasarkan hal tersebut, permasalahan pokok yang hendak dikaji dalam tulisan ini adalah bagaimana urgensi pembentukan Undang-Undang tentang Hak Angket DPR dan apa materi muatannya?

Penelitian dan kajian mengenai hak angket telah dilakukan oleh beberapa penulis, antara lain: 
1. Naswar dalam Jurnal Konstitusi, Volume I, No. 1, November 2012 menulis tentang Hak Angket dalam Konstelasi Ketatanegaraan Indonesia. Dalam tulisan tersebut disimpulkan adanya ketidaktepatan konsepsi hak angket yang ditunjukkan dalam pelaksanaannya, seperti penyelidikan DPR terhadap Buloggate, kasus BLBI dan lain-lain, yang menurut Naswar dapat (bahkan telah) mendistorsi fungsi DPR. ${ }^{1}$

2. Andi Ippeh dalam Jurnal Ilmu Hukum Legal Opinion Edisi 3, Volume 2, Tahun 2014 menulis tentang Keberadaan Hak Angket dalam Melaksanakan Fungsi Pengawasan Dewan Perwakilan Rakyat Terhadap Pemerintah. Hasil penelitiannya menyebutkan bahwa salah satu fungsi DPR ialah fungsi pengawasan terhadap Pemerintah, namun pada kenyataannya DPR belum efektif menjalankan tugas dan fungsi checks and balances. Salah satunya kasus hak angket Bank Century yang menurutnya pada saat itu belum selesai. ${ }^{2}$

3. Subarjo dalam Jurnal Ilmu Hukum Novelty Volume 7 No. 1 Februari 2016 menulis tentang Penggunaan Hak Angket oleh DPR RI dalam Mengawasi Kebijakan Pemerintah. Dalam tulisan tersebut dikatakan bahwa hak angket yang dilakukan oleh DPR hanya menghasilkan keputusan normatif dan lebih cenderung bersifat politis. ${ }^{3}$

4. Meri Yarni dan Yetniwati menulis dalam Jurnal Ilmu Hukum Volume 2 No. 3 Tahun 2011 tentang Pelaksanaan Hak Angket Dewan Perwakilan Rakyat Daerah (DPRD) Kota Jambi. Tulisan tersebut membahas mengenai pelaksanaan hak angket DPRD Kota Jambi terhadap Keputusan Walikota Jambi yang dianggap tidak sesuai dan cacat hukum. Disimpulkan bahwa pelaksanaan

Naswar, "Hak Angket Dalam Konstelasi Ketatanegaraan Indonesia”, Jurnal Konstitusi, Volume I, No. 1, November 2012, hal.1-13.

2 Andi Ippeh, "Keberadaan Hak Angket Dalam Melaksanakan Fungsi Pengawasan Dewan Perwakilan Rakyat Terhadap Pemerintah", Legal Opinion Edisi 3, Volume 2, Tahun 2014, hal. 1-11.

Subarjo, "Penggunaan Hak Angket oleh DPR RI dalam Mengawasi Kebijakan Pemerintah", Novelty Volume 7 No.1 Februari 2016, hal. 71-82. hak angket DPRD Kota Jambi telah berpedoman pada Tatib DPRD Kota Jambi, namun keputusan Panitia Angket DPRD Kota Jambi tidak dapat diproses lebih lanjut karena adanya kesalahan registrasi dan pendaftaran berkas di MA. Disarankan untuk lebih memperhatikan ketentuan formal agar pelaksanaan tugas DPRD Kota Jambi melalui penggunaan hak angket dapat lebih efektif. ${ }^{4}$

5. Fitria dalam Jurnal Cita Hukum Volume 1 No. 1 Juni 2014 menulis tentang Penguatan Fungsi Pengawasan DPR melalui Perubahan Undang-Undang Nomor 10 Tahun 1954 tentang Hak Angket (sic!). Dalam tulisannya dinyatakan bahwa hak angket selama ini berada pada wilayah "abu-abu". Produk keputusan hak angket sebagai produk politik tidak memiliki daya ikat secara yuridis bagi penegak hukum. Hasil angket yang ada selama ini, termasuk hasil angket Pansus Century, seolah "sia-sia" karena tidak memiliki implikasi yang berarti bagi pemerintah. Fitria menyarankan perlunya meninjau ulang peraturan yang menjadi dasar digunakan hak angket agar dapat menjadi instrumen pengawasan bagi DPR terhadap cabang kekuasaan yang lain. ${ }^{5}$

Beberapa penelitian dan kajian tersebut menganalisis mengenai pelaksanaan hak angket yang dilakukan oleh DPR maupun DPRD secara empiris pada periode DPR yang lalu dan tidak membahas secara tuntas mengenai kerangka regulasi. Fitria telah menyampaikan gagasan perlunya penyempurnaan UU Angket, namun dengan dasar atau tujuan penguatan DPR karena rekomendasi Panitia Angket Bank Century tidak ditindaklanjuti. Tulisan tersebut terdapat kekhilafan dalam menyebutkan UU Hak Angket yang seharusnya UU No. 6

\footnotetext{
Meri Yarni dan Yetniwati, "Pelaksanaan Hak Angket Dewan Perwakilan Rakyat Daerah (DPRD) Kota Jambi”, Jurnal Ilmu Hukum Volume 2, Nomor 3 Tahun 2011, hal. 86-96.

Fitria, "Penguatan Fungsi Pengawasan DPR Melalui Perubahan Undang-Undang No. 10 Tahun 1954 tentang Hak Angket", Cita Hukum, Vol. I No. 1 Juni 2014, hal. 79-88.
} 
Tahun 1954, bukan UU No. 10 Tahun 1954. Sementara kajian ini berlatar belakang masalah perbedaan tafsir terhadap pengaturan hak angket DPR terhadap pelaksanaan tugas dan kewenangan KPK dan urgensi pembentukan UU Hak Angket DPR RI pasca-putusan MK.

Kajian ini bertujuan mengetahui urgensi pembentukan Undang-Undang Hak Angket DPR dan mengetahui materi muatan pengaturan hak angket. Tulisan ini secara akademis diharapkan dapat memberikan sumbangan pemikiran bagi pengembangan ilmu hukum tata negara dan secara praktis diharapkan dapat memberikan sumbangan pemikiran bagi pembentukan Undang-Undang tentang Hak Angket DPR RI.

\section{CELAH HUKUM PENGATURAN DAN MATERI MUATAN HAK ANGKET}

A. Celah Hukum Pengaturan Hak Angket

Pengujian terhadap UU Angket diajukan oleh pemohon yang mengatasnamakan perseorangan warga negara Indonesia. Permohonan disampaikan dengan surat bertanggal 26 Januari 2010 yang terdaftar di Kepaniteraan MK pada tanggal 8 Februari 2010 dengan registrasi Nomor 8/PUU-VIII/2010. Di dalam materi permohonan disampaikan bahwa terdapat 2 (dua) undang-undang yang digunakan sebagai acuan pelaksanaan hak angket, yaitu UU Angket dan Undang-Undang Nomor 27 Tahun 2009 tentang tentang MPR, DPR, DPD, dan DPRD. Menurut Pemohon, ada tiga alasan mengapa UU Angket seharusnya menjadi tidak berlaku.

1. Pengaturan tentang hak angket DPR telah diatur antara lain oleh Pasal 77 ayat (3) UU No. 27 Tahun 2009;

2. UU Angket dibuat dengan mengacu konstitusi yang sudah tidak berlaku lagi sejak dikeluarkannya Dekrit Presiden 5 Juli 1959;

3. Asas keberlakuan peraturan perundangundangan menyatakan lex posteriori derogat legi priori (peraturan atau undang-undang yang terbaru mengesampingkan peraturan atau undang-undang yang lama).
Putusan MK menyatakan UU Angket bertentangan dengan UUD 1945 karena landasan konstitusional yang mendasari pembentukan UU Angket adalah UUDS 1950 yang menggunakan sistem pemerintahan parlementer, sementara UUD 1945 menggunakan sistem pemerintahan presidensial. Pertimbangan MK berikutnya adalah tata cara pembentukan dan mekanisme kerja panitia angket yang diatur dalam UU Angket telah diatur juga dalam UU MD3. Apabila UU Angket tetap dipertahankan, akan menimbulkan ketidakpastian hukum yang justru bertentangan dengan UUD 1945.

Putusan MK membatalkan UU Angket, namun bukan membatalkan esensi hak angket sebagai hak yang dimiliki oleh DPR yang berada dalam konstruksi sistem pemerintahan presidensial. Di dalam pertimbangannya, MK menyarankan untuk menyempurnakan UU Hak Angket. Pembentuk undang-undang perlu mengantisipasi dengan membentuk undangundang sebagaimana dimaksud dalam Pasal 20A ayat (4) UUD 1945 mengenai hak-hak DPR dan hak-hak anggota DPR. Secara tidak langsung terdapat amanat dari MK pascapembatalan putusan tersebut untuk membentuk undangundang mengenai hak-hak DPR dan hak-hak anggota DPR pada umumnya, atau UU tentang Hak Angket DPR, pada khususnya.

Dengan tidak berlakunya lagi UU Angket maka dasar hukum pelaksanaan hak angket DPR yang selama ini menggunakan dua undangundang, yaitu UU Angket dan UU MD3, tinggal satu undang-undang, yaitu UU MD3. UU MD3 yang telah mengalami penggantian, yaitu dari UU No. 27 Tahun 2009 menjadi UU No. 17 Tahun 2014 yang kemudian diubah dengan UU No. 42 Tahun 2014. UU MD3 yang saat ini berlaku ternyata tidak secara komprehensif mengatur pelaksanaan hak angket dengan memasukkan ketentuan dari UU Angket yang telah dibatalkan. Hal ini mengakibatkan adanya beberapa celah kekosongan hukum. Perbandingan pengaturan antara UU Angket dan UU MD3 dapat dilihat dari tabel berikut ini. 
Tabel 1.

Perbandingan Materi Muatan UU Angket dan UU MD3

\begin{tabular}{|c|c|c|c|}
\hline No. & HAL & UU ANGKET & UU MD3 \\
\hline 1. & PENGERTIAN & Tidak mengatur pengertian hak angket. & $\begin{array}{l}\text { Mengatur pengertian tentang hak } \\
\text { angket. }\end{array}$ \\
\hline \multirow[t]{9}{*}{2.} & \multicolumn{3}{|c|}{ MEKANISME INTERN DI DPR } \\
\hline & Pengusulan & $\begin{array}{l}\text { sekurang-kurangnya } 10 \text { orang anggota } \\
\text { DPR. }\end{array}$ & $\begin{array}{l}\text { paling sedikit } 25 \text { (dua puluh lima) orang } \\
\text { anggota DPR dan lebih dari } 1 \text { (satu) } \\
\text { fraksi. }\end{array}$ \\
\hline & & diajukan secara tertulis & $\begin{array}{l}\text { disertai dokumen yang memuat paling } \\
\text { sedikit: materi kebijakan dan/atau } \\
\text { pelaksanaan undang-undang yang akan } \\
\text { diselidiki; dan alasan penyelidikan. }\end{array}$ \\
\hline & $\begin{array}{l}\text { Pengambilan } \\
\text { Keputusan }\end{array}$ & $\begin{array}{l}\text { sesudah usul dibicarakan dalam seksi } \\
\text { (untuk konteks sekarang seperti komisi) } \\
\text { terkait, dan putusan memuat perumusan } \\
\text { tentang hal yang akan diselidiki. }\end{array}$ & $\begin{array}{l}\text { mendapat persetujuan dari rapat } \\
\text { paripurna DPR yang dihadiri lebih dari } \\
1 / 2 \text { jumlah anggota DPR dan disetujui } \\
\text { lebih dari } 1 / 2 \text { jumlah anggota DPR yang } \\
\text { hadir. }\end{array}$ \\
\hline & $\begin{array}{l}\text { Pengumuman } \\
\text { dalam Berita } \\
\text { Negara }\end{array}$ & $\begin{array}{l}\text { Keputusan DPR diumumkan dalam } \\
\text { Berita Negara sesuai dengan risalah } \\
\text { DPR, termasuk anggota yang berhak } \\
\text { melakukan pemeriksaan, penambahan, } \\
\text { penggantian, dan pembubaran panitia } \\
\text { angket. }\end{array}$ & $\begin{array}{l}\text { Panitia angket ditetapkan dengan } \\
\text { keputusan DPR yang mencakup jjuga } \\
\text { penentuan biaya panitia angket dan } \\
\text { diumumkan dalam Berita Negara. } \\
\text { Keputusan DPR disampaikan kepada } \\
\text { Presiden. }\end{array}$ \\
\hline & Sifat Rapat & $\begin{array}{l}\text { Pemeriksaan oleh panitia angket dilakukan } \\
\text { dalam rapat tertutup dan bersifat rahasia. }\end{array}$ & $\begin{array}{l}\text { Tidak diatur. (Mengacu pada pengaturan } \\
\text { umum tentang sifat rapat) }\end{array}$ \\
\hline & Masa Kerja & $\begin{array}{l}\text { Tidak tertunda oleh penutupan sidang- } \\
\text { sidang atau pembubaran DPR yang } \\
\text { membentuknya sampai DPR baru } \\
\text { menentukan lain. }\end{array}$ & $\begin{array}{l}\text { Panitia angket melaporkan pelaksanaan } \\
\text { tugasnya kepada rapat paripurna DPR } \\
\text { paling lama } 60 \text { (enam puluh) hari sejak } \\
\text { dibentuknya panitia angket. }\end{array}$ \\
\hline & Anggaran & $\begin{array}{l}\text { Jumlah biaya angket untuk satu tahun } \\
\text { anggaran dicantumkan dalam anggaran } \\
\text { DPR. }\end{array}$ & $\begin{array}{l}\text { Keputusan DPR mencakup juga } \\
\text { penentuan biaya panitia angket. }\end{array}$ \\
\hline & $\begin{array}{l}\text { Laporan Panitia } \\
\text { Angket dan } \\
\text { Keputusan DPR }\end{array}$ & Tidak diatur. & $\begin{array}{l}\text { Diatur secara rinci mengenai jangka } \\
\text { waktu panitia angket melaporkan ke } \\
\text { rapat paripurna, mekanisme pengambilan } \\
\text { keputusan atas laporan panitia angket, } \\
\text { dan tindak lanjut keputusan DPR. }\end{array}$ \\
\hline 3. & \multicolumn{3}{|c|}{ HUKUM ACARA PEMERIKSAAN } \\
\hline & $\begin{array}{l}\text { Pemanggilan } \\
\text { Saksi dan Ahli }\end{array}$ & $\begin{array}{l}\text { Saksi dan ahli datang atas panggilan } \\
\text { tertulis maupun melalui juru sita } \\
\text { pengadilan negeri atau jaksa atas } \\
\text { permintaan panitia angket. Panggilan } \\
\text { disampaikan sekurang-kurangnya } 7 \text { hari } \\
\text { sebelum pemeriksaan. }\end{array}$ & $\begin{array}{l}\text { Panitia angket, dalam melakukan } \\
\text { penyelidikan, selain meminta keterangan } \\
\text { dari Pemerintah, dapat meminta } \\
\text { keterangan dari saksi, pakar, organisasi } \\
\text { profesi, dan/atau pihak terkait lainnya. }\end{array}$ \\
\hline
\end{tabular}




\begin{tabular}{|c|c|c|c|}
\hline \multirow{2}{*}{\multicolumn{2}{|c|}{ HAL }} & UU ANGKET & UU MD3 \\
\hline & & $\begin{array}{l}\text { Panitia angket dapat memerintahkan } \\
\text { saksi atau ahli untuk bersumpah/berjanji } \\
\text { sebelum diperiksa. }\end{array}$ & Tidak diatur \\
\hline & $\begin{array}{l}\text { Pemeriksaan } \\
\text { Saksi dan Ahli }\end{array}$ & $\begin{array}{l}\text { Pemeriksaan saksi dan ahli dilakukan } \\
\text { di tempat yang menurut pertimbangan } \\
\text { tepat untuk itu. Keterangan yang } \\
\text { diberikan dicatat dan dibacakan atau } \\
\text { diberikan untuk dibaca dan sesudahnya } \\
\text { ditandatangani oleh saksi atau ahli. }\end{array}$ & Tidak diatur \\
\hline & $\begin{array}{l}\text { Pemeriksaan } \\
\text { Saksi dan Ahli } \\
\text { di Luar Negeri }\end{array}$ & $\begin{array}{l}\text { Pertanyaan yang diinginkan jawabannya } \\
\text { diberitahukan secara tertulis oleh panitia } \\
\text { angket kepada menteri yang bersangkutan } \\
\text { yang membantu dipenuhinya pertanyaan } \\
\text { itu dengan perantaraan Perwakilan } \\
\text { Indonesia di luar negeri. }\end{array}$ & Tidak diatur \\
\hline & $\begin{array}{l}\text { Saksi dan Ahli } \\
\text { yang Tidak } \\
\text { Hadir }\end{array}$ & $\begin{array}{l}\text { 1. Apabila seorang saksi atau ahli yang } \\
\text { dipanggil jurusita tidak datang, dibuat } \\
\text { berita acara yang memuat keterangan } \\
\text { yang seksama tentang panggilan itu } \\
\text { dan ditandatangani oleh anggota } \\
\text { panitia angket. } \\
\text { 2. Panitia angket, jika memandang } \\
\text { perlu, menyampaikan berita acara } \\
\text { tersebut kepada kejaksaan di tempat } \\
\text { tinggal saksi atau ahli yang lalai itu. } \\
\text { 3. Tuntutan terhadap saksi atau } \\
\text { ahli yang lalai, baik dalam tingkat } \\
\text { pertama maupun dalam tingkat } \\
\text { banding, diperiksa oleh pengadilan } \\
\text { sipil menurut cara yang biasa } \\
\text { dipergunakan untuk memeriksa dan } \\
\text { memutuskan perkara pidana. } \\
\text { 4. Pengadilan negeri di daerah yang } \\
\text { bersangkutan dapat memerintahkan } \\
\text { menyandera saksi atau ahli yang } \\
\text { membangkang; Penyanderaan ini } \\
\text { diputuskan untuk waktu selama- } \\
\text { lamanya seratus hari, tetapi berakhir } \\
\text { apabila saksi atau ahli itu memenuhi } \\
\text { kewajibannya sebelum itu. } \\
\text { 5. Atas permintaan panitia angket, ketua } \\
\text { pengadilan negeri memerintahkan } \\
\text { untuk segera menyandera saksi atau } \\
\text { ahli yang membangkang. } \\
\text { 6. Perintah ketua pengadilan negeri } \\
\text { memuat permintaan yang diajukan } \\
\text { oleh panitia angket, pengangkatan } \\
\text { jurusita yang diwajibkan untuk } \\
\text { membawa saksi atau ahli, dan } \\
\text { penentuan tempat penyanderaan. }\end{array}$ & $\begin{array}{l}\text { 1. Dalam melaksanakan hak angket, } \\
\text { panitia khusus berhak meminta } \\
\text { pejabat negara, pejabat pemerintah, } \\
\text { badan hukum, atau warga masyarakat } \\
\text { untuk memberikan keterangan. } \\
\text { 2. Panitia khusus meminta kehadiran } \\
\text { pejabat negara, pejabat pemerintah, } \\
\text { badan hukum, atau warga masyarakat } \\
\text { secara tertulis dalam jangka waktu } \\
\text { yang cukup dengan menyebutkan } \\
\text { maksud permintaan tersebut dan } \\
\text { jadwal pelaksanaannya. } \\
\text { 3. Pihak yang diundang wajib hadir } \\
\text { untuk memberikan keterangan, } \\
\text { termasuk menunjukkan dan/atau } \\
\text { menyerahkan segala dokumen yang } \\
\text { diperlukan kepada panitia khusus. } \\
\text { 4. Panitia khusus dapat menunda } \\
\text { pelaksanaan rapat akibat } \\
\text { ketidakhadiran pihak yang diundang } \\
\text { karena suatu alasan yang sah. } \\
\text { 5. Dalam hal pihak yang diundang tidak } \\
\text { hadir tanpa alasan yang sah, atau } \\
\text { menolak hadir, panitia khusus dapat } \\
\text { meminta satu kali lagi kehadiran } \\
\text { yang bersangkutan pada jadwal yang } \\
\text { ditentukan. } \\
\text { 6. Dalam hal pihak yang diundang } \\
\text { tidak memenuhi permintaan } \\
\text { kehadiran yang kedua tanpa alasan } \\
\text { yang sah atau menolak hadir, yang } \\
\text { bersangkutan dikenai panggilan paksa } \\
\text { oleh Kepolisian Negara Republik } \\
\text { Indonesia atas permintaan panitia } \\
\text { khusus. }\end{array}$ \\
\hline
\end{tabular}




\begin{tabular}{|c|c|c|c|}
\hline \multirow{2}{*}{\multicolumn{2}{|c|}{ No. }} & UU ANGKET & UU MD3 \\
\hline & & $\begin{array}{l}\text { 7. Dibuat akte yang menyebut perintah } \\
\text { penyanderaan yang salinannya } \\
\text { seketika itu juga diserahkan kepada } \\
\text { orang yang disandera. } \\
\text { 8. Penyanderaan yang diperintahkan } \\
\text { dengan putusan hakim dijalankan } \\
\text { walaupun ada bantahan atau } \\
\text { banding. }\end{array}$ & $\begin{array}{l}\text { 7. Dalam hal panggilan paksa tidak } \\
\text { dipenuhi tanpa alasan yang sah, } \\
\text { yang bersangkutan dapat disandera } \\
\text { paling lama } 15 \text { (lima belas) hari oleh } \\
\text { aparat yang berwajib, sesuai dengan } \\
\text { ketentuan peraturan perundang- } \\
\text { undangan. }\end{array}$ \\
\hline & $\begin{array}{l}\text { Pemeriksaan } \\
\text { Surat/ Dokumen }\end{array}$ & $\begin{array}{l}\text { 1. Panitia angket berhak meminta surat- } \\
\text { surat yang disimpan, kecuali apabila } \\
\text { bertentangan dengan kepentingan } \\
\text { negara. } \\
\text { 2. Apabila seorang saksi atau ahli } \\
\text { tidak memperlihatkan surat-surat } \\
\text { yang dianggap perlu, panitia angket } \\
\text { dapat meminta pengadilan negeri } \\
\text { untuk menyita dan/atau menyalin } \\
\text { surat-surat itu, kecuali jika mengenai } \\
\text { rahasia jabatan dan rahasia dagang. }\end{array}$ & $\begin{array}{l}\text { Tidak diatur secara rinci. Hanya } \\
\text { disebutkan pihak yang diundang wajib } \\
\text { hadir untuk memberikan keterangan, } \\
\text { termasuk menunjukkan dan/atau } \\
\text { menyerahkan segala dokumen yang } \\
\text { diperlukan kepada panitia khusus. }\end{array}$ \\
\hline & $\begin{array}{l}\text { Imunitas bagi } \\
\text { Saksi dan Ahli }\end{array}$ & $\begin{array}{l}\text { Segala keterangan yang diberikan tidak } \\
\text { dapat dipergunakan sebagai bukti dalam } \\
\text { peradilan terhadap saksi, ahli atau } \\
\text { terhadap orang lain. }\end{array}$ & Tidak diatur \\
\hline & $\begin{array}{l}\text { Keterangan } \\
\text { Palsu }\end{array}$ & $\begin{array}{l}\text { KUHP berlaku bagi setiap orang yang } \\
\text { sengaja memberikan keterangan palsu. }\end{array}$ & Tidak diatur \\
\hline & $\begin{array}{l}\text { Ganti Rugi dan } \\
\text { Pembiayaan } \\
\text { Saksi/Ahli }\end{array}$ & $\begin{array}{l}\text { Saksi dan ahli dapat menerima } \\
\text { penggantian kerugian menurut } \\
\text { ketentuan biaya dan penggantian } \\
\text { kerugian bagi saksi-saksi dan ahli pada } \\
\text { pengadilan negeri. }\end{array}$ & Tidak diatur \\
\hline
\end{tabular}

Sumber: UU Angket dan UU MD3.

Berdasarkan perbandingan tersebut, untuk beberapa hal, UU MD3 telah melakukan penyempurnaan terhadap UU Angket, yaitu:

1. memberikan definisi tentang hak angket.

2. memperbaiki syarat pengusulan yang semula hanya sekurang-kurangnya 10 orang anggota DPR, menjadi paling sedikit 25 (dua puluh lima) orang anggota DPR dan lebih dari 1 (satu) fraksi, serta memberikan syarat bahwa pengusulan hak angket harus disertai dengan dokumen yang memuat paling sedikit materi kebijakan dan/atau pelaksanaan undang-undang yang akan diselidiki dan alasan penyelidikan.

3. memperjelas masa kerja panitia angket yang semula tidak terbatas, bahkan tidak tertunda oleh penutupan sidang-sidang atau pembubaran DPR yang membentuknya sampai DPR baru menentukan lain menjadi paling lama 60 (enam puluh) hari sejak dibentuknya panitia angket.

4. mengatur lebih rinci tentang keputusan DPR terhadap laporan panitia angket.

Meskipun ada beberapa penyempurnaan, namun masih terdapat banyak celah kekosongan hukum atau pengaturan yang sumir mengenai pelaksanaan hak angket dalam UU MD3. Kekosongan atau pengaturan yang sumir tersebut terdapat pada ketentuan mengenai pengucapan sumpah/janji saksi dan ahli, pemeriksaan saksi dan ahli termasuk dalam hal saksi/ahli berhalangan atau tidak hadir; tempat pemeriksaan dan pemeriksaan saksi/ahli di luar 
negeri; pemeriksaan surat (dokumen), imunitas bagi saksi dan ahli; keterangan palsu; sifat rapat panitia angket; dan ganti rugi atau pembiayaan saksi/ahli.

\section{B. Materi Muatan Undang-Undang Hak Angket}

Berdasarkan perbandingan yang diuraikan dalam tabel, terdapat 3 (tiga) kelompok materi muatan. Materi muatan yang pertama adalah ketentuan umum yang berisi pengertianpengertian atau definisi. Kelompok yang kedua mengenai mekanisme internal di DPR, mulai dari pengusulan, pengambilan keputusan, pengumuman dalam berita negara, sifat rapat, anggaran termasuk biaya untuk saksi dan ahli, masa kerja, laporan panitia angket, dan pengambilan keputusan serta jenis-jenis atau tindak lanjut keputusan DPR terhadap laporan panitia angket. Kelompok yang ketiga adalah hukum acara pemeriksaan saksi, ahli, dan dokumen. Hukum acara tersebut perlu diatur secara lebih detail dibandingkan yang diatur sekarang dalam UU MD3. Pengaturan secara lebih detail dapat mengacu pada UU Angket dengan beberapa penyesuaian.

\section{Pengertian}

Hal penting yang perlu dimuat dalam undang-undang adalah pengertian mengenai hak angket. Pengertian hak angket sudah terdapat dalam Pasal 79 ayat (3) UU MD3, namun pengertian tersebut masih menimbulkan multi-interpretasi terkait dengan subjek dan objek penyelidikan. Dalam kasus hak angket terhadap pelaksanaan tugas KPK, Ketua Umum Asosiasi Pengajar Hukum Tata NegaraHukum Administrasi Negara (APHTN-HAN), Mahfud MD, menjelaskan ada tiga hal dasar panitia khusus/panitia angket tersebut dinilai cacat hukum. Kesatu, subjek hak angket yakni KPK dinilai keliru karena secara historis hak angket hanya dimaksudkan untuk pemerintah. Hak angket digunakan untuk menyelidiki pelaksanaan undang-undang dan/atau kebijakan pemerintah, misalnya Presiden, Wakil Presiden, para menteri, Jaksa Agung, Kapolri, dan lembaga pemerintah non-kementerian (LPNK), sehingga KPK tidak termasuk di dalamnya. Kedua, objek hak angket, yakni penanganan perkara KPK. Objek penyelidikan hak angket harus memenuhi tiga kondisi, yakni hal penting, strategis dan berdampak luas bagi masyarakat. Ketiga, prosedurnya dinilai salah. Prosedur pembentukan panitia khusus (pansus) diduga kuat melanggar undang-undang karena terkesan dipaksakan. Menurut Mahfud, seharusnya rapat paripurna melakukan voting terhadap usulan hak angket karena seluruh fraksi belum mencapai kesepakatan. Pembentukan pansus terkesan dipaksakan karena baru tujuh fraksi yang mengutus wakilnya, sementara menurut Pasal 201 ayat (3) UU MD3 harus semua fraksi terwakili dalam pansus. ${ }^{6}$

Sebelum membahas mengenai pengertian hak angket, perlu dikemukakan terlebih dahulu mengenai fungsi DPR, mengingat berdasarkan konstruksi Pasal 20A ayat (2) UUD 1945, DPR diberikan hak-hak secara kelembagaan untuk melaksanakan fungsinya. ${ }^{7}$ Hak angket sangat berkaitan erat dengan fungsi pengawasan yang dimiliki oleh DPR. Pengertian mengenai fungsi pengawasan akan digunakan untuk menganalisis pengertian terhadap hak angket, khususnya terhadap siapa atau lembaga mana seharusnya hak angket DPR ditujukan.

Menurut Jimly Asshiddiqie, lembaga perwakilan rakyat diberikan kewenangan untuk melakukan kontrol (pengawasan) dalam tiga hal, yaitu: (i) kontrol atas pemerintahan (control of executive); (ii) kontrol atas pengeluaran (control of expenditure); dan (iii) kontrol atas pemungutan pajak (control of taxation). ${ }^{8}$ Jika dirinci, fungsi kontrol atau pengawasan oleh parlemen sebagai

\footnotetext{
"Pakar Hukum Tata Negara Nilai Cacat Pembentukan Pansus Angket KPK” http://nasional.kompas.com/ $\mathrm{read} / 2017 / 06 / 14 / 16595151 / 132$.pakar.hukum.tata. negara.nilai.cacat.pembentukan.pansus.angket.kpk, diakses tanggal 13 Agustus 2017.

Pasal 20A UUD 1945 didahului dengan ayat (1) yang menyebutkan DPR memiliki fungsi legislasi, fungsi anggaran, dan fungsi pengawasan. Selanjutnya pada ayat (2) disebutkan bahwa dalam melaksanakan fungsinya, selain hak yang diatur dalam pasal-pasal lain UndangUndang Dasar ini, DPR mempunyai hak interpelasi, hak angket, dan hak menyatakan pendapat. Jimly Asshiddiqie, Pengantar Ilmu Hukum Tata Negara, Jakarta: PT. RajaGrafindo Persada, 2016, hal 302.
} 
lembaga perwakilan rakyat dapat dibedakan, yaitu pengawasan terhadap penentuan kebijakan; pelaksanaan kebijakan; penganggaran dan belanja negara; pelaksanaan anggaran dan belanja negara; kinerja pemerintahan; dan pengawasan terhadap pengangkatan pejabat publik (control of political appointment of public officials) dalam bentuk persetujuan atau penolakan, ataupun dalam bentuk pemberian pertimbangan. ${ }^{9}$ Yamamoto mendefinisikan fungsi pengawasan parlemen sebagai "the review, monitoring and supervision of government and public agencies, including the implementation of policy and legislation". ${ }^{10}$

Menurut Masnur Marzuki sifat fungsi dan tugas pengawasan DPR mencakup dua hal, kesatu, pengawasan yang bersifat institusional. Kedua, pengawasan yang bersifat individual. Pengawasan yang bersifat institusional adalah dalam kerangka tugas dan fungsi kelembagaan DPR dalam lingkup cabang kekuasaan legislatif. Pengawasan yang bersifat personal dalam kerangka hak yang melekat pada anggota DPR sebagai wakil rakyat. ${ }^{11} \mathrm{Hal}$ tersebut dilihat dari sisi DPR sebagai pengawas. Terkait dengan objek yang diawasi, berdasarkan beberapa definisi tersebut, bentuk pengawasan yang dilakukan parlemen dilakukan terhadap dua hal, yaitu pemerintah atau lembaga publik dan implementasi kebijakan atau undang-undang.

Selanjutnya perumusan mengenai pengertian hak angket juga perlu ditelusuri secara historis atau asal usul hak angket parlemen. Hak angket pertama kali dikenal di Inggris pada abad XIV, dan bermula dari right to investigate and chastice the abuses of administration. Hak ini pertama kali digunakan oleh parlemen Inggris pada tahun 1376 yang mengakibatkan pemecatan beberapa pejabat istana karena melakukan penyelewengan keuangan. ${ }^{12}$ Dengan mengacu pada pendapat

Ibid.

10 Hironori Yamamoto, Tools for Parliamentary Oversight A Comparative Study of 88 National Parliaments, Geneva: Inter-Parliamentary Union, 2007, hal. 10.

11 Masnur Marzuki, "Fungsi Pengawasan Parlemen Indonesia: Prospek dan Tantangan”, Law Review, Vol. XIV, No. 1 - Juli 2014, hal. 65-78.

12 Arifin Sari Surunganlan Tambunan, Fungsi Dewan Perwakilan Rakyat Republik Indonesia Menurut UUD 1945, Suatu Studi Analisis Mengenai Pengaturannya Tahun 1966-1997, Jakarta; Sekolah Tinggi Hukum Militer, 1998, hal. 158.
E.H. Karsten dan perkembangan penggunaan hak angket, A.S.S. Tambunan menyebutkan ada 4 (empat) jenis angket, yaitu angket di bidang keuangan (financial enquete), angket di bidang politik (political enquete), angket di bidang legislatif (legislative enquete), dan angket soal pemilihan umum (election enquete). Angket yang pertama dilakukan adalah di bidang keuangan (financial enquete). Kemudian berkembang ke bidang politik (political enquete), bidang legislatif (legislative enquete), dan soal pemilihan umum (election enquete). Angket politik adalah suatu penyelidikan yang menghasilkan suatu penilaian baik atau buruk mengenai tindakan dan kelalaian pemerintah. Angket legislatif berhubungan erat dengan hak inisiatif dan merupakan suatu penyelidikan keadaan masyarakat untuk mengetahui apakah memerlukan pengaturan dalam undang-undang, sedangkan angket pemilihan umum adalah penyelidikan mengenai pelanggaran/penyelewengan yang terjadi dalam pemilu. ${ }^{13}$

Dalam penelitian yang dilakukan oleh penulis sebelumnya, tiga jenis angket pernah dilakukan oleh lembaga perwakilan di Indonesia. Financial enquete, terkait dengan Dana Milik Yanatera Bulog dan Kasus Dana Bantuan Sultan Brunei Darussalam kepada Presiden Abdurrahman Wahid, Political enquete, terhadap pemogokan dan keadaan Badan Tekstil Negara di Delanggu, Solo; Sebab Musabab kecelakaan kereta api di Trowek, Tasikmalaya, dan Dana Milik Yanatera Bulog dan Dana Bantuan Sultan Brunei Darussalam kepada Presiden Abdurrahman Wahid. Legislative enquete tentang Usaha untuk Memperoleh dan Cara Mempergunakan Devisen, dan tentang Aparatur Perekonomian Negara. ${ }^{14}$ Data tersebut apabila dilengkapi dengan pembentukan panitia

E.H. Karsten, De Parlementaire Enquete in de Constitutionale Staten, (Utrecht, Kemink \& Zoon, 1860), hal 1-9 dalam Arifin Sari Surunganlan Tambunan, Fungsi Dewan Perwakilan Rakyat Republik Indonesia Menurut UUD 1945, Suatu Studi Analisis Mengenai Pengaturannya Tahun 1966-1997, Jakarta; Sekolah Tinggi Hukum Militer, 1998, hal. 158-159.

14 Novianto M. Hantoro, Pelaksanaan Fungsi Pengawasan Dewan Perwakilan Rakyat Melalui Hak Angket dalam Sistem Ketatanegaraan Republik Indonesia, Tesis, Jakarta; Universitas Indonesia, 2004, hal. 153. 
angket sampai saat ini maka Panitia Angket DPR tentang Bank Century dan Pelindo II dapat dikategorikan dalam financial enquete, sedangkan Panitia Angket Daftar Pemilih Tetap pada Pemilu 2009 masuk dalam kategori election enquete. Dengan demikian, keempat jenis angket pernah dilakukan oleh lembaga perwakilan di Indonesia.

Secara gramatikal, Kamus Besar Bahasa Indonesia (KBBI) mendefinisikan angket dalam tiga pengertian yang salah satunya adalah penyelidikan oleh lembaga perwakilan rakyat terhadap kegiatan pemerintah. ${ }^{15}$ Patrialis Akbar yang pernah menjadi anggota Panitia Ad Hoc III dan I Badan Pekerja MPR memberikan pengertian hak angket adalah hak untuk melakukan penyelidikan terhadap suatu kasus tertentu yang dianggap besar dan menyangkut kepentingan rakyat atau nasional oleh DPR melanggar undang-undang. Dibandingkan dengan hak interpelasi, hak angket lebih kuat dan lebih tinggi derajatnya mengingat sesuai peraturan perundang-undangan dampak penggunaan hak ini dapat berkembang ke arah proses pemakzulan Presiden dan/atau Wakil Presiden. ${ }^{16}$ Penerjemahan angket dengan penyelidikan dikhawatirkan oleh Bagir Manan dapat menimbulkan salah pengertian. Istilah penyelidikan merupakan proses awal dalam pengungkapan dugaan telah terjadi perbuatan pidana, sebagai terjemahan opsporing dalam bahasa Belanda. ${ }^{17}$

Definisi yang berbeda mengakibatkan perbedaan penafsiran terkait pengertian hak angket. Berdasarkan UU MD3, pengertian angket disebutkan pada Pasal 79 ayat (3) sebagai berikut.

Hak angket sebagaimana dimaksud pada ayat (1) huruf b adalah hak DPR untuk melakukan penyelidikan terhadap pelaksanaan suatu undangundang dan/atau kebijakan Pemerintah yang

\footnotetext{
15 "Angket" dalam https://kbbi.web.id/angket, diakses tanggal 2 Oktober 2017.

16 Patrialis Akbar, Lembaga-Lembaga Negara Menurut UUD NRI Tahun 1945, Jakarta: PT. Sinar Grafika, 2012, hal. 62.

17 Bagir Manan, DPR, DPD, dan MPR dalam UUD 1945 Baru, Yogyakarta; FH UII Press, 2003, hal. 38.
}

berkaitan dengan hal penting, strategis, dan berdampak luas pada kehidupan bermasyarakat, berbangsa, dan bernegarayang diduga bertentangan dengan peraturan perundang-undangan.

Pengertian yang terdapat dalam Pasal 79 ayat (3) UU MD3 tidak menyebutkan kepada siapa hak angket DPR ditujukan, baik lembaga maupun perseorangan, namun terhadap apa (sesuatu hal). Pasal 79 ayat (3) UU MD3 menyebutkan bahwa angket ditujukan terhadap pelaksanaan undang-undang dan/ atau kebijakan pemerintah. Adanya frasa "dan/atau" memiliki arti bahwa penyelidikan tersebut dapat dilakukan terhadap pelaksanaan undang-undang saja, terhadap kebijakan pemerintah saja, atau sekaligus terhadap pelaksanaan undang-undang dan kebijakan pemerintah. Definisi tersebut tidak berhenti sampai di situ karena masih ada kondisi yang harus dipenuhi, yaitu harus berkaitan dengan hal penting, strategis, dan berdampak luas pada kehidupan bermasyarakat, berbangsa, dan bernegara. Unsur berikutnya adalah adanya dugaan pelaksanaan undang-undang dan/atau kebijakan pemerintah tersebut bertentangan dengan peraturan perundang-undangan.

Dengan demikian, berdasarkan Pasal 79 ayat (3) UU MD3, hak angket adalah hak DPR untuk melakukan:

1. penyelidikan terhadap pelaksanaan suatu undang-undang;

2. penyelidikan terhadap kebijakan Pemerintah; atau

3. penyelidikan terhadap pelaksanaan suatu undang-undang dan kebijakan Pemerintah; yang berkaitan dengan hal penting, strategis, dan berdampak luas pada kehidupan bermasyarakat, berbangsa, dan bernegara yang diduga bertentangan dengan peraturan perundangundangan.

Penjelasan Pasal 79 ayat (3) UU MD3 menyebutkan:

Pelaksanaan suatu undang-undang dan/atau kebijakan Pemerintah dapat berupa kebijakan yang dilaksanakan sendiri oleh Presiden, Wakil Presiden, menteri negara, Panglima TNI, Kapolri, 
Jaksa Agung, atau pimpinan lembaga pemerintah nonkementerian.

Menurut penulis, penjelasan ayat ini bukan menjelaskan siapa pemerintah, melainkan siapa yang melaksanakan undang-undang/ kebijakan pemerintah tersebut. Adanya frasa "dapat berupa" menimbulkan kesan kalimat tersebut tidak selesai, yaitu ketika ada frasa "dilaksanakan sendiri" maka seharusnya ada kelanjutan "maupun dilaksanakan oleh....". Dengan demikian, pelaksanaan suatu undangundang dan/atau kebijakan pemerintah tersebut dapat berupa kebijakan yang dilaksanakan sendiri oleh pihak-pihak sebagaimana disebutkan secara eksplisit, dan dapat pula yang dilaksanakan oleh pihak lain, di luar yang disebut secara eksplisit di dalam penjelasan.

Pasal 79 ayat (3) maupun penjelasannya tidak mengatur mengenai terhadap siapa atau lembaga mana seharusnya hak angket DPR ditujukan. Perkembangan ketatanegaraan sekarang ini telah melahirkan banyak lembaga negara independen atau lembaga negara sampiran yang seringkali diperdebatkan kedudukannya dengan ukuran Trias Politika. Ni'matul Huda menyebutkan bahwa proses kelahiran lembaga-lembaga sampiran negara merupakan refleksi dari kontestasi dua kecenderungan klasik yang menjadi salah satu pertanyaan besar yang bersifat permanen dalam studi ilmu politik, yakni kecenderungan sentripetal (konsentrasi kekuasaan) dan kecenderungan sentrifugal (pemencaran kekuasaan). ${ }^{18}$ Lebih lanjut dikemukakan oleh Ni'matul Huda, jika pada awalnya kekuatan non-negara membatasi perjuangan mereka hanya untuk merebut ruang bagi mereka sendiri yang telah dipilah-pilah secara ketat -state, civil society, and economic societydalam perkembangan sejak reformasi, telah memperluas hasratnya untuk juga menjangkau kontrol atas ranah negara. Dalam logika seperti ini, lewat lembaga-lembaga sampiran negara, aktor non-negara bisa mengkonversi diri secara

18 Ni'matul Huda, Sengketa Kewenangan Lembaga Negara dalam Teori dan Praktek di Mahkamah Konstitusi, Yogyakarta: FH UII Press, 2016, hal. 76. cepat sebagai aktor yang bertindak atas nama dan untuk kepentingan publik yang selama ini dimonopoli oleh negara. Negara bukan lagi sebuah institusi yang tunggal dan otonom atas masyarakatnya, tetapi bergeser menjadi arena kontestasi dari kekuatan-kekuatan yang ada dalam negara dan masyarakat. Indikasinya jelas terlihat lewat dominannya aktor-aktor nonnegara (para aktivis, ilmuwan, dan sebagainya) dalam menguasai struktur pengambilan keputusan dalam pelbagai lembaga sampiran negara. ${ }^{19}$ Namun demikian, Mukhtie Fadjar berpendapat walaupun terhadap ajaran Montesquieu itu timbul banyak keberatan, tetapi yang penting, yang perlu diambil adalah jiwa dan tujuan dari ajaran tersebut, yaitu bahwa kekuasaan negara itu jangan sampai disentralisasi dalam satu tangan (badan) karena akan menimbulkan kesewenang-wenangan, melainkan harus dibagi sehingga hak asasi warga negaranya terlindungi. Jadi bukan sistem atau caranya yang memisahkan secara mutlak yang dipegang oleh tiga organ. Boleh tidak setuju dengan sistem dan caranya, tetapi jiwa dan tujuannya yang baik perlu diambil, bahwa adanya pembagian kekuasaan negara mutlak diperlukan bagi suatu pembagian negara hukum modern. ${ }^{20}$

Hak angket (dengan nama yang berbedabeda, enquete, inquiry) dimiliki oleh banyak parlemen di dunia, baik yang menggunakan sistem parlementer maupun sistem presidensial. Berdasarkan pengertian dan sejarah penggunaan hak angket tersebut, kecenderungan atau halhal apa saja yang dapat diselidiki melalui angket tidak terbatas pada lembaga pemerintah, namun dalam kerangka pelaksanaan fungsi DPR yaitu pembentukan undang-undang, pengawasan terhadap pelaksanaan undang-undang atau kebijakan pemerintah, dan pengawasan terhadap penyelewengan administrasi dan keuangan. Dengan demikian, apabila hendak dirumuskan terhadap siapa hak angket tersebut ditujukan, ukuran yang paling jelas adalah

Abdul Mukhtie Fadjar, Sejarah, Elemen, dan Tipe Negara Hukum, Malang: Setara Press, 2016, hal. 53. 
pemerintah dan pasangan kerja DPR. Komisi Pemilihan Umum (KPU) bukan lembaga pemerintah melainkan lembaga yang dibentuk oleh konstitusi yang bersifat nasional, tetap, dan mandiri. KPU merupakan pasangan kerja Komisi II yang pernah juga menjadi subjek hak angket DPR sebagai pelaksana dari UU Pemilu. Pembatasan penggunaan hak angket, secara konstitusional hanya dibatasi dalam ranah kekuasaan kehakiman. Dengan kata lain, hak angket DPR tidak dapat mengambil alih masalah penegakan hukum yang menjadi ranah kekuasaan kehakiman. Berdasarkan Pasal 24 ayat (1) UUD 1945, kekuasaan kehakiman merupakan kekuasaan yang merdeka untuk menyelenggarakan peradilan guna menegakkan hukum dan keadilan. Konteks penyelidikan dalam hak angket berbeda dengan penyelidikan pro-justicia atau penyelidikan aparat penegak hukum (opsporing), yaitu sebagai proses awal dalam mengungkapkan dugaan telah terjadi perbuatan pidana. Penyelidikan parlemen terkait dengan fact finding untuk merumuskan suatu kebijakan atau melakukan fungsi pengawasan.

\section{Mekanisme Internal di DPR}

Pengaturan mengenai mekanisme internal di DPR diawali dengan pengajuan usul penggunaan hak angket. Pada saat masih menggunakan dua undang-undang, terdapat perbedaan ketentuan mengenai pengusulan hak angket. Berdasarkan UU Angket, usul untuk mengadakan angket dimajukan dengan tertulis oleh sekurang-kurangnya 10 orang anggota DPR. Sementara di dalam UU MD3, hak angket diusulkan oleh paling sedikit 25 (dua puluh lima) orang anggota DPR dan lebih dari 1 (satu) fraksi. Dengan memperhatikan asas, UU yang baru mengesampingkan UU yang lama, maka yang berlaku adalah ketentuan UU MD3. Untuk saat ini, UU Angket sudah dibatalkan sehingga persyaratan pengusulan yang digunakan adalah UU MD3.

Selain mengenai jumlah pengusul, ada persyaratan formal lain yang harus dipenuhi oleh pengusul. Berdasarkan UU Angket, usul itu harus dibicarakan terlebih dahulu dalam seksi atau seksi-seksi (konteks sekarang komisi atau gabungan komisi) yang bersangkutan sebelum pengambilan keputusan dalam rapat paripurna. Sedangkan di dalam UU MD3, terdapat persyaratan bahwa pengusulan hak angket disertai dengan dokumen yang memuat paling sedikit:

a. materi kebijakan dan/atau pelaksanaan undang-undang yang akan diselidiki; dan

b. alasan penyelidikan.

Esensi dari pengaturan tersebut menunjukkan perlunya ada pembahasan dan pendalaman terlebih dahulu terhadap usulan hak angket. Hal ini dapat dipahami mengingat hak angket merupakan metode lanjutan dari pengawasan yang dimiliki oleh DPR ketika fungsi pengawasan yang dilakukan dengan cara biasa melalui Rapat Kerja (Raker) atau Rapat Dengar Pendapat (RDP) dirasakan kurang efektif. Fokus penyelidikan juga perlu dibahas agar ketika pengambilan keputusan, semua fraksi memahami alasan dan tujuan pembentukan panitia angket tersebut.

Pengambilankeputusan atas usul hak angket DPR menurut UU MD3 dilakukan dalam rapat paripurna dengan persyaratan dihadiri lebih dari $1 / 2$ jumlah anggota DPR dan keputusan diambil dengan persetujuan lebih dari $1 / 2$ jumlah anggota DPR yang hadir. Berdasarkan ketentuan tersebut, hanya dibutuhkan persetujuan dari $50 \%+1$ dari jumlah anggota DPR yang hadir dalam rapat paripurna. Dibandingkan dengan usul menyatakan pendapat, persyaratan disetujuinya usul hak angket lebih ringan. Usul hak menyatakan pendapat disetujui DPR apabila rapat paripurna DPR dihadiri paling sedikit 2/3 (dua per tiga) dari jumlah anggota DPR dan keputusan diambil dengan persetujuan paling sedikit 2/3 (dua per tiga) dari jumlah anggota DPR yang hadir. Dengan jumlah anggota DPR saat ini sebanyak 560 anggota, maka untuk pembahasan usul hak angket, rapat paripurna harus dihadiri oleh paling sedikit 281 anggota dan jika dihadiri dengan jumlah tersebut, maka paling sedikit harus disetujui oleh 141 anggota. Persetujuan dengan mayoritas sederhana ini sama dengan pengambilan keputusan untuk 
usul hak interpelasi dan dapat dikatakan kurang ketat, karena tidak ada persyaratan unsur fraksi, baik dalam kuorum rapat, maupun kuorum sahnya keputusan. Dengan ketentuan seperti itu, usul hak angket dapat saja cukup disetujui oleh 2 fraksi, misalnya untuk DPR periode sekarang, Fraksi PDI Perjuangan dengan jumlah anggota 109 dan Fraksi Partai Golkar dengan jumlah anggota 91. Bukan tidak mungkin di suatu saat nanti salah satu partai politik dapat memperoleh 141 kursi, sehingga persetujuan $50 \%+1$ dari $50 \%+1$ yang hadir jika tanpa persyaratan fraksi cukup dari 1 fraksi. Berdasarkan hal tersebut, persyaratan untuk hak angket sebaiknya ditambahkan dengan kuorum fraksi, yaitu dihadiri dan disetujui oleh lebih dari $1 / 2$ jumlah fraksi.

Mekanisme berikutnya, setelah usul hak angket disetujui adalah pembentukan panitia angket. Perdebatan yang terjadi pada saat ini apakah semua fraksi harus terwakili dalam panitia angket? Pasal 201 ayat (2) UU MD3 menyebutkan bahwa dalam hal DPR menerima usul hak angket, DPR membentuk panitia khusus yang dinamakan panitia angket yang keanggotaannya terdiri atas semua unsur fraksi DPR. Perbedaan penafsiran dapat terjadi terhadap ketentuan ini. Dengan menggunakan penafsiran secara gramatikal, maka frasa "keanggotaannya terdiri dari semua unsur fraksi DPR", maka hal tersebut merupakan sebuah keharusan. Di lain pihak, DPR berpendapat bahwa persyaratan tersebut bukan keharusan namun diserahkan oleh setiap fraksi apakah hendak mengirimkan wakilnya di panitia angket atau tidak. Hal ini didasarkan pada pertimbangan bahwa konstruksi pasal tersebut mengalir dari pengambilan keputusan. Secara normatif DPR perlu membuka kesempatan bagi semua fraksi untuk dapat mengirimkan wakilnya di panitia angket, meskipun pada saat pengambilan keputusan fraksi tersebut menolak. Terlepas apakah kemudian fraksi tersebut mengirimkan wakilnya atau tidak. Jika ada fraksi yang tidak setuju dan merupakan minoritas kemudian tidak mengirimkan wakilnya dengan maksud menghambat, maka dengan pemahaman keterwakilan fraksi adalah keharusan, panitia angket tidak akan terbentuk meskipun sudah disetujui dan DPR tidak akan dapat bekerja karena akan sering terjadi deadlock. Sepanjang keanggotaan panitia angket tersebut memenuhi kuorum lebih dari setengah jumlah fraksi dan lebih dari setengah jumlah anggota dari panitia angket yang berjumlah 30 anggota. ${ }^{21}$

Masalah keharusan semua unsur fraksi terwakili dalam setiap kegiatan di DPR memang menjadi persoalan ketika menggunakan sistem presidensial dengan multipartai. Keharusan perwakilan fraksi akan meningkatkan kecenderungan deadlock. Scott Mainwaring menjelaskan ada tiga alasan sebagai berikut:

First, multiparty presidentialism is espically likely to produce immobilizing executive/legislative deadlock, and such deadlock can destabilize democracy. Second, multipartism is more likely than bipartism to produce ideological polarization, thereby complicating problem often associated with presidentialism. Finally, ... is complicated by the difficulties of interparty coalition building in presidential democracies, with deleterious consequences for democratic stability."22

Berdasarkan hal tersebut, sebaiknya pembentukan panitia angket diatur secara lebih tegas dengan cara bertingkat, yaitu sedapat mungkin semua fraksi terwakili. Apabila ada fraksi yang tidak mengirimkan wakilnya, setidaknya lebih dari setengah jumlah fraksi memiliki wakil di panitia angket.

Berikutnya adalah mengenai sifat rapat panitia angket. UU Angket secara tegas menyatakan bahwa rapat pemeriksaan yang dilakukan oleh panitia angket dilakukan secara tertutup dan bersifat rahasia. Namun dalam peraturan saat ini tidak disebutkan secara tegas karena mengacu pada ketentuan umum rapat pansus di DPR. Dalam praktiknya, rapat-rapat

21 Risalah Sidang MK Perkara Nomor 36/PUU-XV/2017 Perkara Nomor 37/PUU-XV/2017 Perkara Nomor 40/ PUU-XV/2017 Perkara Nomor 47/PUU-XV/2017 tanggal 5 September 2017, hal. 15-16.

22 Efriza. "Relasi Kekuasaan Presiden dan DPR dalam Sistem Presidensial" Kajian Politik Dan Masalah Pembangunan. Volume 12 No. 02. Tahun 2016, hal. 1845-1856. 
pemeriksaan dilakukan secara terbuka bahkan diliput secara langsung. Mengingat esensi pelaksanaan hak angket adalah penyelidikan maka sebaiknya pengaturan mengenai sifat rapat panitia angket ketika melakukan pemeriksaan bersifat tertutup dan rahasia.

Mengenai masa kerja panitia angket, terdapat kelebihan UU MD3 dibandingkan dengan UU Angket karena mengatur mengenai batas waktu kerja panitia angket yakni selama 60 hari kerja. Sementara dalam UU Angket, panitia angket bahkan masih dapat dilanjutkan meskipun DPR telah berganti. Konteks dalam UU Angket karena sistem parlementer dan ada kemungkinan pembubaran DPR sehingga dibuat rumusan bahwa pekerjaan panitia angket tidak tertunda oleh penutupan sidang-sidang atau pembubaran DPR yang membentuknya sampai DPR baru menentukan lain. Untuk konteks sistem presidensial, memang seharusnya ada batas waktu untuk panitia angket. Dalam UU MD3, panitia angket melaporkan pelaksanaan tugasnya kepada rapat paripurna DPR paling lama 60 (enam puluh) hari sejak dibentuknya panitia angket. Setelah menyelesaikan tugasnya, panitia angket menyampaikan laporan dalam rapat paripurna dan selanjutnya laporan tersebut dibagikan kepada semua anggota rapat paripurna DPR mengambil keputusan terhadap laporan panita angket didahului dengan laporan hasil panitia angket dan pendapat akhir fraksi. Keputusan DPR harus mendapatkan persetujuan dari rapat paripurna DPR yang dihadiri lebih dari $1 / 2$ jumlah anggota DPR dan keputusan diambil dengan persetujuan lebih dari $1 / 2$ jumlah anggota DPR yang hadir. Apabila rapat paripurna DPR memutuskan bahwa pelaksanaan suatu undang-undang dan/ atau kebijakan pemerintah yang berkaitan dengan hal penting, strategis, dan berdampak luas pada kehidupan bermasyarakat, berbangsa, dan bernegara bertentangan dengan ketentuan peraturan perundang-undangan, DPR dapat menggunakan hak menyatakan pendapat. Apabila rapat paripurna DPR memutuskan bahwa pelaksanaan suatu undang-undang dan/ atau kebijakan Pemerintah yang berkaitan dengan hal penting, strategis, dan berdampak luas pada kehidupan bermasyarakat, berbangsa, dan bernegara tidak bertentangan dengan ketentuan peraturan perundang-undangan, usul hak angket dinyatakan selesai dan materi angket tersebut tidak dapat diajukan kembali.

Berkaitan tindak lanjut apakah hak angket merupakan bagian dari urutan penggunaan hak-hak DPR yang lain, seperti interpelasi dan menyatakan pendapat maka dapat dikemukakan bahwa hak angket merupakan hak yang berdiri sendiri tidak terkait dengan hak-hak yang lain. Hak DPR tidak harus berkesinambungan dan bertingkat dengan diawali dari interpelasi, dilanjutkan dengan angket, kemudian ditingkatkan lagi menjadi hak menyatakan pendapat, walaupun tidak menutup kemungkinan digunakannya hak menyatakan pendapat setelah dilakukan hak angket. Pada sistem keparlemenan pada umumnya, yang mempunyai keterkaitan adalah interpelasi yang mempunyai akibat sanksi politik yang menuju ke mosi tidak percaya kepada pemerintah, namun hal itu-pun sekarang sudah banyak mengalami modifikasi. Mosi tidak percaya tidak harus berasal dari interpelasi. Interpelasi di beberapa negara juga hanya diartikan sebagai permintaan keterangan tanpa harus berakhir dengan mosi tidak percaya. Hananto Widodo menyebutkan bahwa akibat hukum penggunaan hak interpelasi DPR setelah berlakunya Pasal 7A dan 7B UUD 1945 tidak dapat diarahkan pada pemberhentian Presiden karena Presiden secara konstitusional tidak dapat diberhentikan dengan alasan kebijakannya dianggap merugikan rakyat. ${ }^{23}$ Untuk negara-negara yang menganut sistem presidensial seperti Indonesia saat ini, maka untuk menggantikan presiden, satusatunya jalan yang konstitusional adalah melalui mekanisme pendakwaan/pemakzulan terhadap pelanggaran hukum yang dilakukan presiden atau keadaan presiden tidak memenuhi syarat lagi.

\footnotetext{
Hananto Widodo, "Politik Hukum Hak Interpelasi Dewan Perwakilan Rakyat Republik Indonesia”, Rechtsvinding Volume I Nomor 3, Desember 2012, hal. 419-436.
} 


\section{Hukum Acara Pemeriksaan dan Permintaan Keterangan}

Negara hukum menunjuk ke suatu konsep tentang negara di mana pemerintah atau penguasa dalam menjalankan kekuasaannya tidak didasarkan atas kemauannya semata melainkan atas dasar norma hukum yang berlaku. Semua orang di dalam negara tunduk pada ketentuan hukum, baik sebagai individu, masyarakat, maupun sebagai penguasa. Dengan kata lain, negara hukum adalah negara yang diatur oleh hukum, serta mengatur kehidupan masyarakat atas dasar ketentuan hukum. Jadi unsur yang terpenting di dalam konsep negara hukum adalah adanya "supremasi hukum". ${ }^{24}$

Di dalam negara hukum, segala sesuatu yang terkait dengan hak dan kewajiban warga negara perlu diatur secara tegas dalam norma hukum. Dalam konteks pelaksanaan hak angket, terdapat banyak ketentuan mengenai pemeriksaan saksi dan ahli yang hanya diatur secara sumir kemudian diserahkan pengaturannya lebih lanjut dalam Tatib DPR. Dengan tidak berlakunya UU Angket, terdapat banyak celah hukum dalam hukum acara pemeriksaan saksi dan ini adalah materi muatan UU, bukan materi Tatib DPR. Materi muatan pada UU Angket layak dimasukkan agar hukum acara pemeriksaan menjadi lebih pasti dan lebih rinci.

Berdasarkan pengaturan UU Angket sebelumnya dan dikombinasikan dengan UU MD3 serta pengelompokan yang dilakukan oleh penulis dengan mempertimbangkan kondisi saat ini, materi muatan UU Angket yang berkaitan dengan hukum acara pemeriksaan yang perlu diatur adalah:

1. Pemanggilan Saksi dan Ahli

Setelah diumumkan dalam Berita Negara, saksi-saksi dan ahli-ahli mempunyai kewajiban untuk memenuhi panggilan tertulis dari panitia angket. Apabila tidak diketahui kediaman atau keberadaannya, panitia angket dapat meminta bantuan

24 Galang Asmara, Hukum Kelembagaan Negara, Kedudukan Ombudsman dalam Sistem Ketatanegaraan Republik Indonesia, Yogyakarta: LaksBang PRESSindo, 2016, hal. 30-31. kepada jurusita pada pengadilan negeri menjalankan panggilan saksi-saksi atau ahliahli atas perintah panitia angket langsung atau atas perintah jaksa berhubung dengan permintaan panitia angket. Panggilan saksisaksi atau ahli-ahli harus disampaikan kepada orangnya sendiri atau di tempat tinggalnya, dalam batas waktu yang wajar. UU Angket mengatur sekurang-kurangnya tujuh hari sebelum hari pemeriksaan.

2. Pengucapan Sumpah Sebelum Diperiksa

Panitia angket dapat menyuruh saksi atau ahli yang sudah berumur 16 tahun bersumpah (berjanji) sebelum diperiksa. Saksi-saksi yang akan diperiksa dengan sumpah (janji), bersumpah (berjanji) menurut agama atau kepercayaannya, bahwa mereka akan mengatakan segala hal yang sebenarnya dan tiada lain daripada itu. Ahliahli yang akan diperiksa dengan sumpah (janji), bersumpah (berjanji) menurut agama atau kepercayaannya, bahwa mereka akan memberikan laporan dengan jujur dan benar, sesuai dengan pengetahuannya yang sesungguhnya.

3. Pemeriksaan Saksi dan Ahli

Di dalam UU Angket disebutkan bahwa pemeriksaan saksi dan ahli dilakukan oleh panitia angket di tempat yang menurut pertimbangan tepat untuk itu. Pemeriksaan dapat dilakukan di gedung DPR, namun dapat pula di luar gedung DPR. Keteranganketerangan yang diberikan oleh saksi atau ahli dicatat secara tertulis dan setelah itu dibacakan kepada mereka atau diberikan untuk dibaca dan sesudahnya ditandatangani oleh saksi atau ahli yang bersangkutan. Apabila seorang saksi atau ahli karena sakit berhalangan untuk datang kepada panitia angket di tempat yang telah ditentukan, maka panitia angket, jika menimbang perlu, dapat menugaskan kepada pengadilan negeri yang daerah hukumnya meliputi tempat kediaman saksi atau ahli itu untuk memeriksa mereka di tempat itu, bahkan apabila perlu karena keadaan, di rumah saksi atau ahli itu sendiri. 
4. Pemeriksaan Saksi dan Ahli di Luar Negeri Apabila panitia angket menganggap perlu untuk mendengar saksi atau ahli yang berdiam di luar negeri, maka pertanyaanpertanyaan yang diinginkan jawabannya dapat diberitahukan dengan tertulis oleh panitia angket kepada Menteri Luar Negeri yang membantu dipenuhinya pertanyaanpertanyaan itu dengan perantaraan perwakilan Indonesia di luar negeri.

5. Saksi dan Ahli yang Tidak Hadir

Pengaturan ini yang cukup krusial, karena baik dalam UU Angket maupun UU MD3 sekarang ini berlaku hukuman bagi saksi dan ahli yang tidak hadir. Dalam UU Angket diatur bahwa apabila seorang saksi atau ahli yang dipanggil oleh jurusita secara patut namun tidak datang maka tentang hal itu dibuat berita acara yang memuat keterangan-keterangan yang seksama tentang panggilan itu dan ditandatangani oleh anggota-anggota panitia angket yang hadir. Panitia angket, jika memandang perlu, menyampaikan berita acara tersebut kepada kejaksaan di tempat tinggal saksi atau ahli yang lalai itu. Tuntutan terhadap saksi atau ahli yang lalai, baik dalam tingkat pertama maupun dalam tingkat banding, diperiksa oleh pengadilan menurut cara yang biasa dipergunakan untuk memeriksa dan memutuskan perkara pidana. Berita acara tentang saksi atau ahli yang tidak memenuhi panggilan, yang dibuat oleh panitia angket merupakan bukti yang lengkap tentang apa yang tertulis di dalamnya, kecuali jika ada bukti lain yang menyatakan sebaliknya. Pengadilan negeri di daerah yang bersangkutan dapat memerintahkan menyandera saksi atau ahli yang membangkang. Penyanderaan ini diputuskan untuk waktu selama-lamanya seratus hari, tetapi berakhir apabila saksi atau ahli itu memenuhi kewajibannya sebelum itu. Tentang penyanderaan ini dibuat akte yang menyebut perintah penyanderaan yang salinannya seketika itu juga diserahkan kepada orang yang disandera. Penyanderaan yang diperintahkan dengan putusan hakim dijalankan walaupun ada bantahan atau banding. UU Angket mengatur secara lebih detil, sementara dalam UU MD3 hanya mengatur dalam hal pihak yang diundang tidak memenuhipermintaan kehadiran yang kedua tanpa alasan yang sah atau menolak hadir, yang bersangkutan dikenai panggilan paksa oleh Kepolisian Negara Republik Indonesia atas permintaan panitia khusus. Dalam hal panggilan paksa tidak dipenuhi tanpa alasan yang sah, yang bersangkutan dapat disandera paling lama 15 (lima belas) hari oleh aparat yang berwajib, sesuai dengan ketentuan peraturan perundangundangan. Ketentuan dalam MD3 terlalu sumir sehingga seringkali sulit untuk dilaksanakan, termasuk oleh kepolisian yang menyatakan bahwa tidak ada hukum acaranya.

6. Pemeriksaan Surat/Dokumen

Masalah ini belum cukup diatur di dalam UU MD3. Dalam UU Angket diatur secara lengkap bahwa panitia angket berhak meminta kepada Menteri yang bersangkutan, surat-surat yang disimpan oleh pegawai-pegawai kementerian yang dipimpin oleh Menteri itu, untuk diperiksa. Menteri memberi kesempatan kepada panitia angket untuk memeriksa suratsurat itu, kecuali apabila pemeriksaan surat itu akan bertentangan dengan kepentingan negara. Apabila seorang saksi atau ahli tidak bersedia memperlihatkan surat-surat yang dianggap perlu untuk diperiksa oleh panitia angket maka panitia angket dapat meminta kepada pengadilan negeri di daerah hukum yang bersangkutan untuk menyita dan/ atau menyalin surat-surat itu, kecuali jika surat-surat itu mengenai hal-hal yang bersangkutan dengan rahasia jabatan dan rahasia dagang. Beberapa hal yang perlu dicermati dalam pengaturan ini adalah mengenai pengertian kepentingan negara, rahasia negara, rahasia dagang, atau rahasia 
jabatan seperti apa yang dapat dikecualikan dari pemeriksaan panitia angket.

7. Imunitas bagi Saksi dan Ahli

Hal ini sama sekali tidak diatur dalam UU MD3. Dalam UU Angket diatur bahwa segala keterangan yang diberikan kepada panitia angket tidak dapat dipergunakan sebagai bukti dalam peradilan terhadap saksi atau ahli itu sendiri yang memberikan keterangan atau terhadap orang lain.

8. Keterangan Palsu

Selain terdapat ketentuan mengenai imunitas, diatur pula ketentuan mengenai keterangan palsu. Perlu dinyatakan bahwa KUHP berlaku bagisetiap orangyang sengaja memberikan keterangan/laporan palsu. Dalam hal ini, berita acara pemeriksaan merupakan bukti yang lengkap tentang apa yang tertulis di dalamnya, kecuali jika ada bukti lain yang menyatakan sebaliknya.

Hal-hal tersebut merupakan materi muatan yang minimal harus diatur dalam undangundang agar terdapat kejelasan mengenai hukum acara pemeriksaan saksi dan ahli. UU sebaiknya tidak mengamanatkan lebih lanjut untuk diatur dalam Tatib mengingat masalah pemeriksaan ini menyangkut hak dan kewajiban warga negara yang harus diatur di tingkat undang-undang. Perlu dipilah peraturan yang diatur dalam UU dan yang diatur dalam Tatib DPR. Dalam hal terkait dengan pembatasan hak seseorang maka harus diatur dengan UU, sedangkan terkait dengan tertib persidangan cukup diatur dengan Tatib.

\section{PENUTUP}

Berdasarkan hasil analisis di atas, dapat disimpulkan bahwa urgensi penyempurnaan kerangka pengaturan mengenai pelaksanaan hak angket, Kesatu, untuk menindaklanjuti putusan MK sekaligus menjalankan amanat Pasal 20A ayat (4) UUD 1945 agar diatur ketentuan mengenai hak-hak DPR dalam undang-undang. Kedua, untuk menghindari adanya celah kekosongan hukum, mengingat beberapa pengaturan dalam UU Angket yang telah dibatalkan belum diatur secara komprehensif dalam UU MD3. Ketiga, untuk menghindari adanya multi-interpretasi norma sebagaimana yang terjadi pada saat ini.

Materi muatan UU Angket nantinya paling tidak mengatur mengenai beberapa hal yang apabila dikelompokkan menjadi tiga, yaitu: pengertian-pengertian, mekanisme internal di DPR, dan hukum acara pemeriksaan saksi, ahli, dan dokumen. Hal-hal tersebut harus diatur secara komprehensif. Disarankan agar RUU tentang Hak Angket didaftarkan di dalam Program Legislasi Nasional (Prolegnas) agar dapat segera disusun naskah akademis dan RUU nya oleh DPR periode ini.

\section{DAFTAR PUSTAKA}

\section{Jurnal:}

Efriza. "Relasi Kekuasaan Presiden dan DPR dalam Sistem Presidensial" Kajian Politik dan Masalah Pembangunan. Vol. 12 No. 02. Tahun 2016.

Fitria. "Penguatan Fungsi Pengawasan DPR melalui Perubahan Undang-Undang No. 10 Tahun 1954 tentang Hak Angket". Cita Hukum. Vol. I No. 1, Juni 2014.

Ippeh, Andi. "Keberadaan Hak Angket Dalam Melaksanakan Fungsi Pengawasan Dewan Perwakilan Rakyat Terhadap Pemerintah". Legal Opinion Edisi 3, Volume 2. Tahun 2014.

Marzuki, Masnur. "Fungsi Pengawasan Parlemen Indonesia: Prospek dan Tantangan". Law Review, Vol. XIV, No. 1 - Juli 2014.

Naswar. "Hak Angket Dalam Konstelasi Ketatanegaraan Indonesia". Jurnal Konstitusi. Vol. I, No. 1, November 2012.

Subarjo. "Penggunaan Hak Angket oleh DPR RI dalam Mengawasi Kebijakan Pemerintah". Novelty. Volume 7 No. 1, Februari 2016. 
Widodo, Hananto. "Politik Hukum Hak Interpelasi Dewan Perwakilan Rakyat Republik Indonesia”. Rechtsvinding. Volume I Nomor 3, Desember 2012.

Yarni, Meri dan Yetniwati. "Pelaksanaan Hak Angket Dewan Perwakilan Rakyat Daerah (DPRD) Kota Jambi". Ilmu Hukum. Volume 2, Nomor 3 Tahun 2011.

\section{Buku:}

Akbar, Patrialis. Lembaga-Lembaga Negara Menurut UUD NRI Tahun 1945. Jakarta: PT. Sinar Grafika. 2012.

Asmara, Galang. Hukum Kelembagaan Negara, Kedudukan Ombudsman dalam Sistem Ketatanegaraan Republik Indonesia. Yogyakarta: LaksBang PRESSindo. 2016.

Asshiddiqie, Jimly. Pengantar Ilmu Hukum Tata Negara. Jakarta: PT. RajaGrafindo Persada. 2016.

Fadjar, Abdul Mukhtie. Sejarah, Elemen, dan Tipe Negara Hukum. Malang: Setara Press. 2016.

Manan, Bagir. DPR, DPD, dan MPR dalam UUD 1945 Baru. Yogyakarta; FH UII Press, 2003.

Huda, Ni'matul. Sengketa Kewenangan Lembaga Negara dalam Teoridan Praktek di Mahkamah Konstitusi. Yogyakarta: FH UII Press. 2016.

Tambunan, Arifin Sari Surunganlan. Fungsi Dewan Perwakilan Rakyat Republik Indonesia Menurut UUD 1945, Suatu Studi Analisis Mengenai Pengaturannya Tahun 1966-1997. Jakarta; Sekolah Tinggi Hukum Militer, 1998.
Yamamoto, Hironori. Tools for Parliamentary Oversight A Comparative Study of 88 National Parliaments. Geneva: Inter-Parliamentary Union, 2007.

\section{Tesis:}

Hantoro, Novianto M. Pelaksanaan Fungsi Pengawasan Dewan Perwakilan Rakyat Melalui Hak Angket dalam Sistem Ketatanegaraan Republik Indonesia. Tesis. Jakarta; Universitas Indonesia, 2004.

\section{Internet:}

"Angket" dalam https://kbbi.web.id/angket, diakses tanggal 2 Oktober 2017.

"Pakar Hukum Tata Negara Nilai Cacat Pembentukan Pansus Angket KPK" http:// nasional.kompas.com/read/2017/06/ 14/16595151/132.pakar.hukum.tata.negara. nilai.cacat.pembentukan.pansus.angket. kpk, diakses tanggal 13 Agustus 2017.

\section{Dokumen:}

Risalah Sidang MK Perkara Nomor 36/PUU. XV/2017 Perkara Nomor 37/PUU-XV/2017 Perkara Nomor 40/PUU-XV/2017 Perkara Nomor 47/PUU-XV/2017, tanggal 5 September 2017. 